Jurnal Pendidikan Bahasa dan Sastra Indonesia is licensed under

A Creative Commons Attribution-Non Commercial 4.0 International License

\title{
Pelanggaran Maksim pada Tuturan Remaja Perempuan Yatim: Kajian Psikopragmatik
}

\author{
Alfian Rokhmansyah ${ }^{1)}$, Purwanti ${ }^{2)}$, Nur Ainin ${ }^{3)}$ \\ 1) Universitas Mulawarman, Samarinda, Indonesia \\ E-mail: alfian.rokhmansyah@gmail.com \\ 2) Universitas Mulawarman, Samarinda, Indonesia \\ E-mail:purwanti.030991@gmail.com \\ 3) Universitas Mulawarman, Samarinda, Indonesia \\ E-mail: nainin961@gmail.com
}

\begin{abstract}
Abstrak. Penelitian ini bertujuan untuk menjelaskan bentuk pelanggaran maksim yang dilakukan seorang remaja perempuan yatim dan faktor-faktor yang memengaruhi tuturannya. Penelitian ini adalah penelitian lapangan dengan pendekatan kualitatif yang berbentuk studi kasus. Pemaparan data dilakukan secara deskriptif. Objek penelitian (OP) adalah seorang remaja perempuan yatim berusia 21 tahun. Data utama penelitian adalah tuturan dalam kegiatan tindak tutur sehari-hari dari OP. Sedangkan data sekunder berupa identitas diri OP. Hasil penelitian menunjukkan bahwa pelanggaran maksim yang dilakukan OP, yaitu (a) maksim kearifan, (b) maksim kedermawanan, (c) maksim pujian, (d) maksim kerendahan hati, dan (e) maksim kesepakatan. Adapun faktor yang memengaruhi cara berbahasa OP, yaitu (a) kurang mendapat perhatian menyebabkan bentuk tuturan OP condong kasar, (b) posisi sebagai anak sulung dalam keluarga disiplin rendah menyebabkan OP berani mengungkapkan gagasan secara bebas, dan (c) kehilangan sosok teman diskusi menyebabkan OP selalu berusaha mencari teman diskusi untuk mengetahui suatu hal ataupun menyelesaikan masalah.
\end{abstract}

Kata kunci: psikopragmatik; pelanggaran maksim; tuturan; remaja perempuan yatim

\section{Pendahuluan}

Berpikir dan berbahasa merupakan dua aktivitas yang saling melengkapi dan terjadi dalam kurun waktu relatif bersamaan (Ali dan Asrori, 2016:126). Oleh karena itu, seseorang yang dapat mengontrol emosi akan lebih stabil dalam penggunaan bahasa, begitu pun sebaliknya. Remaja sebagai seseorang yang sedang dalam pencarian jati diri identik dengan sifat labil, terutama dalam pengendalian emosi. Ketika seorang remaja merasa senang, maka akan lebih mudah bahagia dan ketika sedih akan lebih mudah depresi. Kondisi inilah yang umumnya membuat seorang remaja terkenal dengan gaya berbahasa kurang sopan atau menggebu-gebu. Kondisi tersebut menurut Yusuf (2016:122) membuat seorang remaja membutuhkan dukungan lebih dari orang terdekat, terutama orang tua. Orang tua memiliki peran sebagai pengajar, pelatih, dan pemberi contoh. Maka, ketidakhadiran salah satu atau kedua orang tua dapat mengakibatkan perkembangan seorang anak tidak maksimal atau mengalami stagnasi.

Hal tersebut dapat terjadi pada remaja yatim. Yatim adalah seorang anak yang salah satu atau kedua orang tuanya telah meninggal dunia (Muhsin, 2003:25). Maka yang dimaksud remaja yatim, yaitu seorang anak yang ayahnya telah meninggal dunia ketika di usia remaja. Atas dasar tersebut, penelitian ini menggunakan objek penelitian seorang remaja perempuan yatim. Remaja tersebut saat itu berusia 17 tahun ketika ayahnya meninggal. Selama proses pemakaman, remaja tersebut tidak sedikit pun menangis untuk meluapkan kesedihan.

Saat ini, remaja perempuan yatim tersebut telah berusia 21 tahun, namun dalam beberapa kesempatan terkadang masih bersikap kekanak-kanakan terutama saat bersama teman-temannya. Hal yang paling mencolok dari sikapnya terlihat pada tata cara atau gaya berbahasa dalam berinteraksi. Remaja perempuan yatim tersebut tidak 
memberikan perbedaan cara berbahasa dalam proses menyampaikan maksud tuturan, baik dengan orang yang lebih tua, lebih muda, maupun sebaya.

Dengan adanya latar belakang sebagai remaja perempuan yatim dan fenomena pelanggaran maksim yang dilakukan, maka penelitian ini bertujuan untuk menjelaskan bentuk pelanggaran maksim yang dilakukan seorang remaja perempuan yatim dan faktor-faktor yang memengaruhi tuturan.

Dalam melakukan tindak tutur, peserta tutur diikat oleh prinsip-prinsip tuturan, yaitu prinsip kerja sama dan prinsip sopan santun yang memiliki maksim-maksim (kaidah percakapan) di dalamnya. Prinsip sopan santun menurut Leech (2015:206-207) adalah prinsip tindak tutur yang berkenaan dengan hubungan antara penutur, lawan tutur, dan kesopanan terhadap pihak ketiga (persona ketiga). Di dalam prinsip sopan santun terdapat enam maksim yang pengelompokannya sesuai dengan penggunaan jenis tindak tutur ilokusi, yaitu: (a) maksim kearifan, (b) maksim kedermawanan, (c) maksim pujian, (d) maksim kerendahan hati, (e) maksim kesepakatan, dan (f) maksim simpati.

Perkembangan bahasa memiliki hubungan yang sangat erat dengan perkembangan berpikir. Menurut Yusuf (2016:118) perkembangan berpikir individu tampak dalam perkembangan bahasanya, yaitu kemampuan membentuk pengertian, menyusun pendapat, dan menarik simpulan. Menurut Mainizar (2013) keterampilan berbahasa diperoleh melalui pengalaman-pengalaman seseorang di dalam hidupnya terhadap lingkungan, baik keluarga, sekolah, maupun masyarakat.

Keluarga sebagai salah satu faktor pengaruh perkembangan bahasa memiliki pengaruh yang sangat besar. Menurut Yusuf (2016:122), hubungan yang sehat (penuh perhatian dan kasih sayang) antara orang tua dengan anak akan membuat perkembangan bahasa anak terfasilitasi dengan baik. Sebaliknya, jika hubungan antara orang tua dan anak tidak sehat (keras atau kasar, kurang kasih sayang, dan kurang perhatian) akan membuat anak mengalami kesulitan dan kelambatan dalam perkembangan berbahasa. Seorang anak yang kurang mendapat perhatian dalam latihan dan pemberian contoh berbahasa yang baik akan membuat bahasa anak cenderung mengalami stagnasi atau kelainan, seperti: gagap dalam berbicara, tidak jelas dalam mengungkapkan kata-kata, merasa takut untuk mengungkapkan pendapat, dan terbiasa berkata kasar atau tidak sopan.

Hurlock (melalui Mainizar, 2013:98) menambahkan faktor-faktor yang memengaruhi perkembangan bahasa, yaitu jenis kelamin, jenis disiplin, posisi urutan dalam keluarga, berbahasa dua, dan besarnya keluarga. Anak yang dibesarkan dengan disiplin yang cenderung lemah akan lebih banyak bicara. Sedangkan anak yang orang tuanya bersikap kasar dan acuh, akan cenderung membuat anak tidak ingin berbicara atau menyampaikan permasalahan dan keinginannya kepada orang tuanya. Dalam kedudukan di keluarga, anak sulung cenderung akan didorong untuk bicara dari pada adiknya namun orang tua lebih mempunyai banyak kesempatan untuk berbicara dengan adik-adiknya.
Sedangkan anak tunggal akan lebih banyak didorong untuk bicara dan orang tua turut berbicara dengannya. Dalam keluarga besar, disiplin lebih otoriter sehingga menghambat anak untuk berbicara sesukanya.

\section{METODE}

Jenis penelitian ini merupakan penelitian lapangan dengan korpus data berupa teks lisan, yaitu tindak tutur. Selain itu, jenis penelitian ini bersifat studi kasus sehingga hanya menggunakan satu objek penelitian. Dengan begitu, data hanya berasal dari satu sumber dan bersifat apa adanya, sesuai konteks yang menyertai tuturan. Penelitian ini menggunakan pendekatan kualitatif dengan pemaparan secara deskriptif untuk menjelaskan bentuk tuturan objek penelitian saat berinteraksi. Dalam penelitian ini, pendekatan kualitatif dipadukan dengan teori psikopragmatik. Adapun sumber data penelitian ini adalah seorang remaja perempuan yatim yang sejak penelitian ini dimulai telah berusia 21 tahun. Remaja tersebut berusia 17 tahun ketika ayahnya meninggal. Sedangkan data penelitian ini terdiri dari dua, yaitu tuturan yang digunakan dalam interaksi sehari-hari dan data penunjang berupa identitas diri atau latar belakang objek penelitian.

Penelitian ini menggunakan teknik pengumpulan data berupa teknik libat cakap, teknik simak bebas libat cakap, dan teknik wawancara. Ketiga teknik tersebut dikombinasikan dengan teknik sadap dan catatan lapangan. data yang telah diperoleh selanjutnya dianalisis menggunakan teknik analisis interaktif yang terdiri dari tiga komponen, yaitu reduksi data, sajian data, dan penarikan simpulan.

\section{HASIL DAN PEMBAHASAN}

Berdasarkan tujuan penelitian yang ingin dicapai, pembahasan akan dipaparkan berdasarkan bentuk pelanggaran maksim dan faktor yang memengaruhi tuturan OP.

\section{A. Bentuk Pelanggaran Maksim}

Hasil penelitian menunjukkan bahwa terdapat pelanggaran prinsip sopan santun pada tuturan seorang remaja perempuan yatim yang menjadi objek penelitian. Pelanggaran tersebut meliputi pelanggaran maksim kearifan, kedermawanan, pujian, kerendahan hati, dan kesepakatan. Adapun modus atau maksud pelanggaran tersebut untuk memberikan nasihat, memerintah, mengungkapkan kekesalan, membanggakan diri, dan membantah.

\section{1) Maksim Kearifan}

Maksim kearifan menuntut setiap anggota tutur agar meminimalkan kerugian orang lain dan memaksimalkan keuntungan orang lain. Setiap orang yang mematuhi maksim ini akan mendapatkan citra diri sebagai orang yang santun dan beradab dalam bertutur. Berikut ini data tuturan yang melanggar maksim kearifan.

Data 1.

OP : Yang perhatian itu yang seperti apa, Bang? (1) 
$\mathrm{P} 2$

OP : Kek gitu kah? (3)

: Kamu udah makan belum? (2)

P3 : Bisa... tergantung situasi itu bisa... (4)

OP : Tuh, Sot... dengar! Intinya, jangan melakukan sesuatu apapun itu yang menurutmu bisa, ee... pada umumnya... (5)

P3

: Gini-gini bentuk perhatian, misalkan jangan lupa salat, ya. Jangan lupa makan, ya.... (6)

P4 : Bagus kan? Itu dalam it's truelly friend, udah salat belum, udah makan belum? (7)

Tindak tutur tersebut terjadi pada tanggal 27 September 2017 di depan sekretariat organisasi. Tindak tutur tersebut melibatkan empat anggota tutur. OP telah lama ingin menasihati P4 agar menjaga sikap dengan laki-laki. OP menilai bahwa sikap P4 terlalu berlebihan dengan laki-laki sehingga menyebabkan laki-laki tersebut berharap. Sebelumnya, OP tidak pernah memiliki pengalaman menjalin hubungan dengan laki-laki sehingga dia takut penjelasan yang disampaikan tidak dipercaya P4. Oleh karena itu, OP lebih dulu meminta penjelasan kepada P3 tentang alasan laki-laki menaruh harapan kepada seorang perempuan.

Tuturan (5) berpusat kepada P4 sebagai bentuk tindak tutur tipe direktif dengan maksud memberi nasihat. Tuturan Tuh, Sot... dengar!, OP mencoba meyakinkan P4 bahwa perhatian dapat memiliki makna lain jika diberikan kepada lawan jenis. Meskipun tuturan memberi nasihat tidak memberikan keuntungan maupun kerugian, namun dapat dianggap sebagai pemanfaatan posisi. Selain itu, tuturan tersebut juga bersifat memaksa agar dipercaya dan dilaksanakan oleh P4 sehingga OP terkesan tidak memiliki sopan santun dalam menyampaikan nasehat. Oleh karena itu, tuturan OP dianggap tidak sopan karena tidak diawali kalimat interogatif Bolehkah saya usul? atau Bolehkah saya memberi nasihat?

\section{2) Maksim Kedermawanan}

Maksim kedermawanan menuntut setiap anggota tutur agar meminimalkan keuntungan diri sendiri dan memaksimalkan kerugian diri sendiri. Setiap orang yang mematuhi maksim ini akan mendapatkan citra diri sebagai orang yang pandai menghormati orang lain. Dengan demikian, kehidupan yang harmonis dan penuh toleransi akan tercipta. Berikut ini data tuturan yang melanggar maksim kedermawanan.

\section{Data 2. \\ OP : Jangan diam aja na, Kem! (1) \\ P2 : Aku enggak tahu mesti ngapain. (2) \\ OP : Ambilkan papan scanner di tasku! (3) \\ P2 : Iya. (4) \\ OP $\quad$ : Catat di bettle, pre pupa, instar 2! (5)}

Tindak tutur tersebut terjadi pada tanggal 17 Maret 2018 di Kebun Raya Unmul Samarinda (KRUS). Sebelumnya, OP sebagai penutur meminta P2 untuk menemani penelitian. P2 merupakan mahasiswa bidang Ilmu Sosial sehingga dia tidak memiliki bekal pengetahuan untuk membantu penelitian OP. Oleh karena itu, P2 hanya menunggu sambil memainkan telepon genggam. Akhirnya, ketika OP menemukan kesulitan, dia menegur P2 untuk membantu mencatat data.

Tuturan OP terpusat kepada P2 sebagai bentuk tindak tutur tipe direktif dengan maksud memerintah. Pada tuturan (1) jangan diam aja na, Kem! Bukan berarti P2 benar-benar berdiam diri. Tuturan OP bermaksud memerintah P2 agar melakukan sesuatu yang membantu penelitiannya. Selanjutnya, pada tuturan (3) dan (5) OP mengarahkan P2 untuk mencatat data yang telah diperoleh. Tuturan OP (1), (3), dan (5) tergolong pelanggaran maksim kedermawanan. Hal tersebut karena OP berusaha memaksimalkan keuntungan diri sendiri dengan memerintah P2 melakukan hal yang diinginkan. Kedekatan antara penutur dengan lawan tutur menyebabkan OP tidak menggunakan kata tolong dalam tuturannya. Oleh sebab itu, OP terkesan tidak memiliki rasa hormat kepada lawan tutur.

\section{3) Maksim Pujian}

Maksim pujian menuntut setiap anggota tutur agar memaksimalkan rasa hormat kepada orang lain dan meminimalkan rasa tidak hormat kepada orang lain. Setiap orang yang mematuhi maksim ini akan mendapatkan citra diri sebagai orang yang tahu sopan santun dan pandai menghargai orang lain. Dengan demikian, komunikasi dan hubungan interpersonal antara penutur dengan lawan tutur akan terjalin harmonis. Selain itu, tiap anggota tutur akan memiliki keinginan untuk saling menghargai satu sama. Berikut ini data tuturan yang melanggar maksim pujian.

Data 3.

OP : Bapaknya ini pura-pura lupa atau gimana sih, kubilang. (1)

P2 : Bukan pura-pura lupa. Orang yang terlalu pintar itu kadang sering lupa. (2)

OP : Aku yakin, ya. Dia itu kek gitu itu garagara.... (3)

P2 : Nggak usah su'udzon! (4)

OP : Ketidakmampuan dia. Iya, Kem. Aku yakin seratus persen. (5)

Tindak tutur tersebut terjadi pada tanggal 18 November 2017 di sekretariat organisasi. Ketika itu, OP bercerita tentang dosen pembimbing skripsinya yang tiba-tiba menolak konsep penelitian setelah sebelumnya menyetujui. Selama proses bertutur, P2 selalu memberikan tanggapan kepada OP meskipun tidak memiliki latar pengetahuan yang sama. Tuturan OP bertujuan untuk mengekspresikan diri kepada P2.

Tuturan OP pada kalimat (3) dan (5) terpusat kepada persona ketiga sebagai bentuk tindak verbal tipe representatif untuk menuduh. OP menuduh dosen pembimbing (persona ketiga) tiba-tiba menolak karena tidak mampu membimbing ide penelitiannya. Pada tuturan (3) $a k u$ yakin, ya. Dia itu kek gitu gara-gara (5) ketidakmampuan dia, OP memaksimalkan rasa tidak hormat kepada persona ketiga dengan merendahkan kemampuan dosen 
pembimbingnya. Selain itu, OP juga menggunakan deiksis persona ketiga dia untuk menyebut orang yang lebih tua darinya.

Tuturan menuduh tersebut dilakukan dengan sengaja oleh OP untuk melampiaskan perasaan kecewa yang dirasakannya. Hal tersebut terlihat pada tuturan Iya, Kem. Aku yakin seratus persen. yang menunjukkan bahwa OP bersungguh-sungguh dengan tuturannya. Meski orang yang bersangkutan tidak mengetahui, namun tuturan OP dapat memberikan kesan buruk tentang dosen pembimbingnya kepada P2. Selain itu, tuturan (3) dan (5) menunjukkan bahwa OP tidak memiliki rasa menghargai terhadap dosen pembimbingnya. Dengan adanya usaha memaksimalkan rasa tidak hormat kepada orang lain tersebut, maka tuturan OP tergolong pelanggaran maksim pujian.

\section{4) Maksim Kerendahan Hati}

Maksim kerendahan hati menuntut setiap anggota tutur agar memaksimalkan ketidakhormatan kepada diri sendiri dan meminimalkan rasa hormat kepada diri sendiri. Setiap orang yang mematuhi maksim ini akan mendapatkan citra diri sebagai orang yang rendah hati atau tidak sombong. Berikut ini data tuturan yang melanggar maksim kerendahan hati.

\section{Data 4.}

P1 : Kenapa sih kamu gampang betul nangis? (1)

OP : Kamu tidak bisa mengira se-strong apa aku. So strong. I am tough woman. (2)

Tindak tutur tersebut terjadi pada tanggal 16 Desember 2017 di ruang sekretariat organisasi. OP dan P1 ketika itu sedang membahas suatu hal yang bersifat pribadi. P1 merupakan teman dekat OP. P1 sering melihat OP menangis karena hal-hal remeh. Meskipun dekat, OP tidak pernah menceritakan suatu hal yang pribadi tentang hidupnya, begitu pula OP. Tuturan P1 bertujuan untuk mengenal OP lebih jauh dengan menanyakan alasannya mudah menangis.

Tuturan OP (2) terpusat pada lawan tutur (P1) sebagai bentuk tindak verbal tipe representatif untuk menyatakan fakta. OP menjawab pertanyaan P1 dengan memberikan pernyataan tentang sisi dirinya yang lain. OP memaksimalkan rasa hormat kepada diri sendiri dengan menyatakan bahwa dia merupakan perempuan yang sangat kuat. Pernyataan tersebut ditekankan kembali oleh OP pada tuturan (2) I am tough woman yang berarti 'aku perempuan tangguh'. Tuturan tersebut mengandung maksud ingin menunjukkan kepada P1 bahwa meski mudah menangis, namun dirinya bukan perempuan lemah. Oleh sebab itu, OP membanggakan sisi tangguh dirinya yang tidak diketahui oleh P1. Dengan adanya maksud tersebut, maka tuturan OP tergolong pelanggaran maksim kerendahan hati.

\section{5) Maksim Kesepakatan}

Maksim kesepakatan menuntut setiap anggota tutur agar memaksimalkan kesepakatan di antara mereka dan meminimalkan ketidaksepakatan di antara mereka. Maksudnya, setiap anggota tutur dituntut agar sebisa mungkin saling menunjukkan kesepakatan tentang topik yang dibicarakan. Jika tidak mungkin, maka penutur diharapkan dapat berkompromi dengan melakukan kesepakatan sebagian. Setiap orang yang mematuhi maksim ini akan mendapatkan citra diri sebagai orang yang pengertian dan pandai menghargai pendapat orang lain. Berikut ini data tuturan yang melanggar maksim kesepakatan.

Data 5.

OP : Kenapa mereka suka nyakiti? (1)

P2 : Di pikiran kita itu kan nyakiti, di pikiran mereka belum tentu begitu. (2)

OP : Nah, seharusnya mereka juga melihat dari berbagai sisi terhadapku. Bukan aku saja yang berpikir seperti itu kepada mereka. (3)

P2 : Harusnya. Tapi gini... (4)

OP : Kalau gitu aku juga bisa tapi. Kalau mereka bisa tapi aku juga bisa tapi. (5)

P2 : Iya, iya. Begini, begini. Tapi begini, apa iya orang banyak ini harus diturutin dengan satu orang ini. (6)

OP : Loh, salah sudah Mbak kalau kek gini. Enggak bisa Mbak. (7)

P2 : Loh, kita kan enggak bisa mengendalikan, apalagi hitungannya kita yang di bawah nih, ya.. Kita di bawah dan posisi mereka di atas, dan kita sendirian dan kita mau menghardik orangorang yang di atas, enggak bisa. Kecuali kalau kita di atas, mereka di bawah, kita bisa melakukan hal itu. (8)

OP : Bisa lah. (9)

P2 : Coba aja. Kalau saya sih enggak berhasil. Makanya saya yang merubah diri saya. Makanya saya yang berubah. (10)

Data tindak tutur (3) terjadi pada tanggal 21 Mei 2017 di aula gedung SC ketika sedang mengikuti perayaan hari jadi suatu organisasi. OP sebagai penutur mengajak diskusi P2 sebagai petutur yang merupakan seorang senior di organisasi tersebut. Saat itu, OP sedang merasa diperlakukan tidak adil dengan sikap beberapa senior yang suka bertindak dan bersikap semaunya. P2 yang memahami kondisi tersebut mencoba memberikan penjelasan kepada OP.

Tuturan OP pada (5), (7), dan (9) terpusat kepada lawan tutur $(\mathrm{P} 2)$ sebagai bentuk tindak verbal tipe representatif untuk menolak penjelasan P2. Pada tuturan (5), OP menolak penjelasan P2 bahkan sebelum selesai menyampaikan penjelasan. Tuturan kalau gitu aku juga bisa tapi. Kalau mereka bisa tapi aku juga bisa tapi, OP menolak kesepakatan sebagian yang dituturkan P2. Penolakan tersebut ditegaskan dengan penggunaan reduplikasi tapi di setiap unsur kalimat. Selain itu, ketidaksepakatan tersebut juga dituturkan dengan intonasi tinggi.

Selanjutnya pada tuturan (7), OP berusaha memaksimalkan ketidaksepakatan sekaligus mengecam penjelasan P2. Pada tuturan loh, salah sudah Mbak kalau kek gini. Enggak bisa, Mbak. OP menolak serta 
menyalahkan penjelasan yang disampaikan P2. Penggunaan kata sudah memiliki fungsi sebagai penegasan. Terakhir, pada tuturan (9), P2 melakukan ketidaksepakatan terhadap penilaian OP dengan intonasi yang lebih tegas dari tuturan sebelumnya. OP kembali menolak penjelasan P2 dengan mengatakan bisa lah. Maksudnya, dari penjelasan tidak bisa yang disampaikan $\mathrm{P} 2$, menurut $\mathrm{OP}$ hal tersebut bisa dilakukan sehingga dia menolak penjelasan $\mathrm{P} 2$.

Ketiga tuturan tersebut sengaja dilakukan OP untuk mempertahankan nilai kebenaran yang dipahaminya, yaitu jika seseorang ingin dimengerti, maka orang tersebut juga harus mengerti orang lain. Oleh sebab itu, OP berusaha memaksimalkan ketidaksepakatan dengan lawan tutur (P2). Tuturan OP tersebut memberikan kesan egois karena melakukan pengecaman. Selain itu, tuturan OP juga dinilai tidak sopan karena ketidaksepakatan tersebut dilakukan kepada P2 sebagai seorang senior. Meskipun dalam bertutur OP menyebut Mbak sebagai penghargaan, namun sikap yang ditunjukkan tidak memperlihatkan bentuk penghargaan. Dengan demikian, tuturan OP tergolong pelanggaran maksim kesepakatan.

\section{B. Faktor yang Memengaruhi Tuturan}

Pelanggaran maksim yang dilakukan oleh OP merupakan dampak dari latar belakang psikologi penutur. Adapun penjelasannya sebagai berikut.

1) Kurang Mendapat Perhatian

Orang tua OP merupakan pekerja, ayahnya bekerja di perusahaan sawit sedangkan ibunya memiliki usaha kue. Sejak kecil, OP sudah terbiasa melakukan aktivitas di luar rumah. Oleh karena itu, dia lebih dekat dengan teman sebaya daripada orang tuanya. Kurangnya kedekatan antara OP dengan orang tua menyebabkan OP merasa kurang diperhatikan. Hal tersebut semakin dirasakan ketika OP memilih untuk melanjutkan SMA jauh dari rumah. Selama indekos, OP tidak pernah ditelepon oleh orang tuanya.

Kurang perhatian yang dirasakan OP merupakan salah satu akibat hubungan tidak sehat antara dia dengan orang tuanya. Akhirnya, hubungan tidak sehat tersebut menyebabkan bahasa OP cenderung mengalami stagnasi atau kelainan, seperti terbiasa berkata kasar atau tidak sopan. Berbahasa tidak sopan yang dilakukan OP terlihat pada pelanggaran maksim kearifan dan maksim kedermawanan.

Pelanggaran maksim kearifan (data 1 tuturan 5) terjadi karena OP menyampaikan nasihat dengan menunjuk langsung ke objek atau sasaran topik pembicaraan. Selain itu, OP juga menggunakan intonasi tinggi dan nada memaksa agar P4 percaya. Tuturan Tuh, Sot... dengar! terkesan kasar karena mengubah suasana seakan P4 telah melakukan kesalahan yang sama berulang kali. Sedangkan tuturan intinya, jangan melakukan sesuatu apapun itu yang menurutmu bisa, eе... pada umumnya... OP memosisikan diri sebagai orang yang paling benar. Jika dilihat dari sudut pandang etika, maka tidak seharusnya OP menasihati P4 secara langsung dalam lingkungan tindak tutur tersebut karena dapat menjatuhkan harga diri $\mathrm{P} 4$.
Adapun pelanggaran maksim kedermawanan (data 2 tuturan 1, 3, dan 5) terjadi karena OP memerintah atau meminta bantuan tanpa menggunakan kata tolong. Pada tuturan ambilkan papan scanner di tasku! dan catat di bettle, pre pupa, instar 2! OP seakan menempatkan posisi P2 sebagai asisten atau pesuruh. Selain kasar, tanpa menggunakan kata tolong ketika meminta bantuan juga dapat dianggap sebagai sikap tidak menghormati. Kedua pelanggaran maksim tersebut merupakan dampak dari kurang mendapatkan perhatian. Seorang anak yang kurang mendapatkan perhatian, secara tidak langsung juga akan kurang mendapatkan pembelajaran dari orang tua. Hal tersebut menyebabkan OP kurang mendapatkan pembelajaran yang tepat untuk dicontoh.

\section{2) Posisi sebagai Anak Sulung di Keluarga Disiplin Rendah}

OP merupakan anak sulung dari dua bersaudara. Orang tua OP memberikan kebebasan kepada anak-anaknya untuk memutuskan keinginan. Selain itu, OP juga dibiasakan untuk mandiri dalam segala hal. Dengan tingkat kedisiplinan yang rendah, OP lebih bebas bersosialisasi dengan orang banyak, terutama teman sebaya.

OP sebagai anak sulung dituntut untuk lebih aktif berbicara sehingga dia terbiasa berani dalam menyampaikan hasil berpikir. Selain itu, tingkat kedisiplinan yang rendah juga mendukung OP bebas dalam berbicara atau mengungkapkan pemikiran. Namun kebebasan yang tidak dikontrol dapat menyebabkan terjadi kesalahan dalam bertutur hingga pelanggaran sopan santun. Berbahasa tidak sopan yang dilakukan OP tersebut terlihat pada pelanggaran maksim pujian.

Pelanggaran maksim pujian (data 3 tuturan 3 dan 5) terjadi karena psikologi OP sedang dikuasai perasaan kecewa sehingga dengan sengaja merendahkan harga diri persona ketiga. Pada tuturan aku yakin, ya. Dia itu kek gitu itu gara-gara... (3) ketidakmampuan dia. OP sengaja menuduh dengan mengatakan bahwa dosen pembimbingnya tidak mampu membimbing. Jika dilihat dari konteks tuturan yang menunjukkan bahwa OP sebelumnya telah melakukan bimbingan, maka tuduhan tersebut bermaksud untuk merendahkan kemampuan intelektual persona ketiga. Kemampuan berani menyampaikan pemikiran tersebut menyebabkan OP tidak dapat mengontrol tuturan ketika sedang emosi. Oleh sebab itu, OP berani menyampaikan tuduhan secara tegas terhadap dosen pembimbingnya di hadapan P2. Meski demikian, OP tidak pernah berani menyampaikan tuduhan, kecaman, atau semua tuturan emosional secara langsung kepada orang yang bersangkutan. Hal tersebut karena OP hanya bebas mengungkapkan pemikiran hanya kepada orang terdekat.

\section{3) Kehilangan Sosok Teman Diskusi}

OP berusia 17 tahun ketika ayahnya meninggal dalam kecelakaan lalu lintas. Usia 17 tahun tergolong masa remaja. Masa remaja merupakan masa penyesuaian diri terhadap gejolak akibat pertentangan nilai-nilai. Untuk menghadapi gejolak tersebut, OP membutuhkan teman diskusi dan guru 
untuk mengenal arti kehidupan. Ketiadaan sosok ayah menyebabkan OP merasa sangat kehilangan dan tidak memiliki sosok panutan.

Ketiadaan sosok ayah tersebut menyebabkan OP merasa kesulitan memahami suatu kondisi dan orang sekitar. Selain itu, OP juga selalu merasa ada masalah di dalam dirinya. Dengan beragam gejolak tersebut, OP berusaha melampiaskan dengan mengajak diskusi orang sekitar, serta menyanggah pendapat lawan tutur untuk mendapat penjelasan. Usaha OP dalam mencari penjelasan tersebut terlihat pada pelanggaran maksim kesepakatan.

Pelanggaran maksim kesepakatan (data 5 tuturan 5, 7, dan 9) terjadi karena penjelasan yang disampaikan P2 tidak sesuai dengan standar nilai kebenaran yang dipahami OP. Pada tuturan Kenapa mereka suka nyakiti? OP berusaha mengajak diskusi P2 untuk mencari tahu alasan seseorang berlaku tidak adil. Dari diskusi tersebut, OP berusaha memahami seseorang dari sudut pandangnya dan sudut pandang orang lain. Namun ketika alasan yang didapat dirasa tidak logis, OP akan dengan sengaja menyanggah berdasarkan standar nilai kebenaran yang diyakininya. Semakin sering OP menyanggah, maka akan semakin banyak dan detail penjelasan yang didapatkan. Setelah penjelasan yang diperoleh dapat dipahami dan logis, OP akan berusaha mengubah konsep pemikirannya. Hal tersebut menunjukkan bahwa OP selalu membutuhkan teman diskusi untuk membantu memperluas wawasannya. Sikap egois yang ditunjukkan ketika menyanggah merupakan bentuk strategi agar lawan tutur berusaha memahaminya secara pelan-pelan.

\section{SIMPULAN}

Berdasarkan hasil dan pembahasan yang telah dijabarkan sebelumnya, maka dapat disimpulkan bahwa terdapat lima jenis pelanggaran maksim yang dilakukan OP. pelanggaran tersebut, yaitu maksim kearifan, maksim kedermawanan, maksim pujian, maksim kerendahan hati, dan maksim kesepakatan. Berdasarkan latar belakang psikologi OP, maka pelanggaran maksim tersebut terjadi karena kurang mendapat perhatian, posisi sebagai anak sulung di keluarga disiplin rendah, dan kehilangan sosok teman diskusi.

\section{DAFTAR PUSTAKA}

Adriana, I. (2008). "Memahami Pola Perkembangan Bahasa Anak dalam Konteks Pendidikan”. Tadris, 3(1), pp. 106-120. Retrieved from http://ejournal.stainpamekasan.ac.id/index.php/tadris/ article/view/229

Ahmadi, A. \& Jauhar, M. (2015). Dasar-Dasar Psikolinguistik. Jakarta: Prestasi Pustaka.

Ali, M. \& Asrori, M. (2016). Psikologi Remaja: Perkembangan Peserta Didik. Jakarta: Bumi Aksara.

Chaer, A. (2009). Psikolinguistik: Kajian Teoretik. Jakarta: Rineka Cipta.

Chaer, A. (2010). Kesantunan Berbahasa. Jakarta: Rineka Cipta.

Cummings, L. (2007). Pragmatik: Sebuah Perspektif Multidisipliner. Yogyakarta: Pustaka Pelajar.

Leech, G. (2015). Prinsip-Prinsip Pragmatik.. Jakarta: Penerbit Universitas Indonesia (UI-Press).

Mainizar. (2013). "Peranana Orang Tua dalam Pembinaan dan Pengembangan Bahasa pada Anak Usia 2-6 Tahun". Marwah, 17(2), pp. 91-105. DOI:10.24014/marwah.v12i1.516.

Nadar, F. X. (2013). Pragmatik dan Penelitian Pragmatik. Yogyakarta: Graha Ilmu.

Rohmadi, M. (2016). "Kajian Psikopragmatik pada Tindak Tutur Meminta Mas Yuma dan Mas Briliant pada Ranah Keluarga Yuma Perkasa Group”. Prosiding Prasasti, pp. 95-103. Retrieved from https://jurnal.uns.ac.id/prosidingprasasti/article/view/ 462

Sarwono, S. W. (2016). Psikologi Remaja (Edisi Revisi). Jakarta: Raja Grafindo Persada.

Yusuf, S. (2016). Psikologi Perkembangan Anak dan Remaja. Bandung: Remaja Rosdakarya. 